\title{
Response of Douglas-fir leaf area index and litterfall dynamics to Swiss needle cast in north coastal Oregon, USA
}

\author{
Aaron R. WeISKITTEL*, Douglas A. MAGUIRE \\ Department of Forest Science, Oregon State University, Corvallis, OR 97331, USA
}

(Received 22 May 2006; accepted 6 September 2006)

\begin{abstract}
Sources of variation in leaf area index (LAI; $\mathrm{m}^{2}$ of projected leaf area per $\mathrm{m}^{2}$ of ground area) and its seasonal dynamics are not well known in managed Douglas-fir stands, despite the importance of leaf area in forecasting forest growth, particularly in stands impacted by insects or disease. The influence of Swiss needle cast (SNC) on coastal Douglas-fir (Pseudotsuga menziesii var. menziesii [Mirb] Franco) LAI and litterfall dynamics was quantified by destructively sampling 122 stems from 36 different permanent plots throughout north coastal Oregon, USA, and by monitoring litterfall for 3 years in 15 of these plots. LAI, total annual litterfall, and the seasonal distribution of foliage and fine woody litterfall were all influenced by stand structural attributes, physiographic features, and SNC severity. Mean LAI in this study was $5.44 \pm 2.16$. The relatively low LAIs were attributed primarily to the effects of SNC on foliage retention, and secondarily to its direct measurement by hierarchical foliage sampling in contrast to indirect measurement by light interception or tree allometry. For a given stand structure and SNC severity, LAI was 36\% greater in the fall after current year foliage was fully developed and older aged classes had not yet senesced. Annual litterfall expressed as a proportion of LAI at the start of the growing season varied from 0.13 to 0.53 and declined with increasing initial LAI. SNC also shifted more of the annual foliage litterfall to earlier in the spring. Fine woody litterfall experienced a different seasonal shift as the peak occurred later in the year on sites with high SNC, but this only occurred on northerly aspects. Defoliation from the endemic SNC pathogen can drastically reduce LAI and change both total and seasonal foliage litterfall patterns.
\end{abstract}

Swiss needle cast / Douglas-fir / defoliation / leaf area index / foliage loss dynamics

Résumé - Réponse de l'index foliaire (LAI) et de la dynamique de chute de litière du Douglas à la rouille suisse dans la zone côtière du Nord Oregon. Les sources de variation de l'index foliaire (LAI, $\mathrm{m}^{2}$ de surface projetée des feuilles par $\mathrm{m}^{2}$ de surface de sol) et sa dynamique saisonnière ne sont pas bien connues dans les peuplements aménagés de Douglas, malgré l'importance de la surface foliaire dans les prévisions de la croissance des forêts, particulièrement dans les peuplements touchés par des insectes ou les maladies. L'influence de la rouille suisse (SNC) sur l'index foliaire et la dynamique de chute de litière de Pseudotsuga menziesii var. menziesii [Mirb.] Franco ont été quantifiées grâce à un échantillonnage destructif de 122 tiges dans 36 placeaux permanents dans la zone côtière du Nord Oregon (USA) et le suivi pendant 3 ans des chutes de litière dans 15 de ces placeaux. L'index foliaire, la chute annuelle totale de litière, et la distribution du feuillage et la litière ligneuse fine ont tous été influencés par les attributs structuraux, les caractéristiques physiographiques et la gravité de SNC. Dans cette étude la moyenne de l'index foliaire était de 5,44 $\pm 2,16$. Les index foliaires relativement faibles ont été essentiellement attribués aux effets de SNC sur le maintien du feuillage, et secondairement sur ses mesures directes par un échantillonnage hiérarchisé par opposition aux mesures indirectes par interception de la lumière ou par des méthodes d'allométrie au niveau des arbres. Pour une structure de peuplement et une gravité de SNC données, l'index foliaire a été $36 \%$ plus élevé à l'automne après le plein développement du feuillage de l'année en cours et avant la sénescence des classes plus âgées. La chute annuelle de litière exprimée en proportion de l'index foliaire au début de la saison de croissance a varié de 0,13 à 0,53 et a baissé avec l'augmentation de l'index foliaire initial. La SNC a aussi enlevé plus que la chute annuelle de feuillage de la litière plus tôt au printemps. La litière ligneuse fine a été rencontrée à différents moments dans la saison alors que le pic s'est produit plus tard dans l'année dans les sites présentant une SNC élevée, mais ceci s'est seulement produit dans les expositions au nord. La défoliation par le pathogène endémique SNC peut réduire considérablement l'index foliaire et change à la fois les modèles de chute totale et de chute saisonnière de litière.

rouille suisse / sapin de Douglas / défoliation / index foliaire / dynamique des pertes de feuillage

\section{INTRODUCTION}

The photosynthetic surface area of a forest stand determines its potential net primary productivity [51]. In most tree species, leaf surface area comprises the vast majority of the total photosynthetic surface area and is most commonly measured as projected or one-sided leaf area. Total leaf area and, to a lesser extent, its spatial and seasonal distribution control many ecophysiological processes and conditions, including interception of precipitation and solar radiation, within-stand micro-

\footnotetext{
* Corresponding author: aaron.weiskittel@ oregonstate.edu
}

climate, transpiration, and gas exchange [9]. In many analyses and models of net primary production, leaf area index (LAI) expressed as total one-sided leaf area per unit of ground area (e.g., $\mathrm{m}^{2} \mathrm{~m}^{-2}$ ) is a convenient measure that serves well as a driver of potential production [51]. Several recent reviews highlight the importance of this stand attribute, the challenge of measuring it accurately, and new techniques that promise more expedient and cost effective field estimates [9, 23, 67]. The importance of LAI is driven in part by the sensitivity of process-based models of forest production to this variable, for example, 3-PG [14], Soil-Plant-Atmosphere (SPA) [32], 
MAESTRO [33], and BGC [68]. In the SPA model, Licata [32] found that increasing the value of LAI from the reference value minus $50 \%$ to the reference value plus $50 \%$ caused a $44 \%$ increase in gross primary production.

Direct estimation of LAI is often hindered by the arduous tasks of collecting a statistically valid set of samples in the field and separating foliage from woody material in the lab, but indirect estimation is plagued by uncertainty in the effects of non-photosynthetic tissues when using techniques such as light transmission or laser hits. Estimates from allometric relationships may be particularly unreliable in stands that have been partially defoliated [28]. Furthermore, most indirect estimates of LAI appear accurate up to a LAI of only 5-6 [18], a level exceeded by many plantations in the Pacific Northwest $[60,65]$. In short, these challenges limit the number of stand-level estimates of total leaf area, to the extent that relatively little is known about causes of variation in total leaf area and its annual and seasonal fluctuations. This knowledge gap limits the reliability of process-based models for predicting growth, particularly under changing environmental and stand structural conditions.

The seasonal dynamics of LAI in evergreen coniferous species has received less attention than that of deciduous species, probably because LAI is perceived to be more stable during the growing season in species with an evergreen habit. However, seasonal variation in stand LAI can be relatively large and is related to species-specific differences in foliar longevity [62]. Stand LAI in a 32-year-old eastern white pine (Pinus strobus L.) plantation ranged from 3.5 in the dormant season to a maximum of 5.3 in late July [63]. A similar trend has been reported for a young, widely spaced $P i$ nus radiata plantation in New Zealand [69] and a Pinus taeda plantation with varying water and nutrition amendments in the southern United States [52]. Our understanding of the seasonal variation in stand LAI is based on only a few Pinus species and a narrow range in environmental conditions, so further investigation is required to account for the effect of seasonal dynamics on forest production [62].

The amount and proportion of stand leaf area shed annually are also quite variable and appear to be controlled by several environmental factors, only some of which are manipulated silviculturally. The assumed $20-25 \%$ annual turnover rate of leaf area in mechanistic growth models for Douglas-fir (Pseudotsuga menziesii [Mirb] Franco) has significant implications for growth predictions in these models $[4,32,43]$. Although numerous studies have quantified average litterfall rates across a range of species and stand conditions $[8,61]$, few involve concurrent assessment of LAI or total foliage mass and, hence, few models exist for explaining the patterns of variability in retained and lost foliage through stand development, after silvicultural treatment, and in response to weather [31,44]. Although fluctuations in annual litterfall should be predictable, the insufficient number of estimates and the high variability among litter traps within a stand make it difficult to establish simple relationships between stand characteristics and annual turnover from currently available information [47]. Further, the influence of stand health on litterfall rates has not been clearly established. Some studies have found no correlation between defoliation and litterfall $[5,46]$, while other studies have documented a positive correlation [2,24]. Ultimately, a predictive model for foliage loss is important not only for accurately estimating LAI and net primary production, but also for predicting litter input to soil and the size of soil carbon pools [31].

Currently, over 72000 ha of Douglas-fir plantations in the Coast Range of Oregon, USA, are showing symptoms of Swiss needle cast (SNC), reflecting the dramatic increase of this disease in recent years [25]. The disease has reduced tree vigor and caused premature needle abscission [40], significantly altering several crown structural attributes [65] and leading to average volume growth losses as high as $52 \%$ in severely affected plantations [38]. Growth losses presumably result from both reduced LAI [65] and disruption of gas exchange in surviving needles [39]. Better understanding of the disease's influence on LAI may improve predictions of growth losses. Moreover, differences in LAI imposed by SNC provide an opportunity to evaluate monthly and annual leaf area turnover across a range in initial LAI.

The goal of this analysis was to test and quantify the relationship between LAI and foliage litterfall across a range in stand and site conditions, including SNC severity. The specific objectives were to test the null hypothesis that the following quantities were invariant among stands with a wide range in SNC severity: (1) LAI; (2) foliage and fine woody litterfall; and (3) monthly distribution of foliage litterfall. Swiss needle cast was expected to cause a decrease in standing LAI, an increase in annual litterfall (including foliage turnover rate), and an upward shift in the proportion of foliage litterfall occurring in the late spring/early summer.

\section{METHODS}

\subsection{Study sites}

All plots were located in the Oregon Coast Range; within $32 \mathrm{~km}$ of the Pacific Ocean, north of Newport, Oregon (N 44 40', W $124^{\circ}$ $\left.4^{\prime}\right)$ and south of Astoria, Oregon (N 46 $7^{\prime}$, W $123^{\circ} 45^{\prime}$ ). The climate in this study area is humid oceanic, with a distinct dry summer and a cool, wet winter. rainfall varies from approximately 180 to $300 \mathrm{~cm}$ year $^{-1}$, and January mean minimum and July mean maximum temperatures range from -2 to $2{ }^{\circ} \mathrm{C}$ and from 20 to $28{ }^{\circ} \mathrm{C}$, respectively [38]. Variation in precipitation and temperature for this area is strongly correlated with elevation and proximity to the coast. Elevation ranged from 45 to $550 \mathrm{~m}$ and all aspects were represented in this study.

The sampled plantations were 10- to 60-years old at breast height and contained $\geqslant 75 \%$ Douglas-fir by basal area, with varying amounts of naturally regenerated western hemlock (Tsuga heterophylla (Raf.) Sarg.) and other conifer and hardwood species (Tab. I). Thirty-six stands were systematically sampled for this study to represent a range of SNC severity. A fuller description of the plot selection and sampling is given in Weiskittel et al. [66]. 
Table I. Definitions and units of symbols used in this paper.

\begin{tabular}{|c|c|c|}
\hline Symbol & Definition & Units \\
\hline AGE & Average stand breast height age & years \\
\hline ASP12 & Cosine transformation of slope and aspect [\%SLOPE $\times \cos (4 \times \pi \times$ ASPECT $/ 360)]$ & _ \\
\hline ASP22 & Sine transformation of slope and aspect [\%SLOPE $\times \sin (4 \times \pi \times$ ASPECT/360)] & _ \\
\hline BA & Total stand basal area & $\mathrm{m}^{2} \mathrm{ha}^{-1}$ \\
\hline $\mathrm{CL}$ & Tree crown length & $\mathrm{m}$ \\
\hline CLSA & Crown sparseness index (ratio of crown length to sapwood area at crown base; increases with greater levels of SNC) & $\mathrm{cm} \mathrm{cm}^{-2}$ \\
\hline CLSA $_{\text {PLOT }}$ & Mean crown sparseness index for the plot & $\mathrm{cm} \mathrm{cm}^{-2}$ \\
\hline CM_\%FOL & Cumulative proportion of leaf area turnover since bud break & - \\
\hline CM_\%WD & Cumulative proportion of fine woody material shed since bud break & - \\
\hline COAST & Distance from the Pacific Ocean & $\mathrm{km}$ \\
\hline COSA & Cosine transformation of aspect $[\cos (2 \times \pi \times$ ASPECT/360) $]$ & - \\
\hline DBH & Diameter at breast height & $\mathrm{cm}$ \\
\hline DSBF & Days since bud flush & days \\
\hline $\mathrm{DQ}_{\mathrm{DF}}$ & Stand quadratic mean diameter for Douglas-fir & $\mathrm{cm}$ \\
\hline ELEV & Stand elevation above sea level & $\mathrm{m}$ \\
\hline FOLRET & Stand mean foliage retention (decreases with greater SNC) & years \\
\hline HT & Total tree height & $\mathrm{m}$ \\
\hline $\mathrm{HCB}$ & Tree height to crown base & $\mathrm{m}$ \\
\hline LITTER $_{\mathrm{FOL}}$ & Annual foliage litterfall per unit of ground area & $\mathrm{m}^{2} \mathrm{~m}^{-2}$ \\
\hline LAI & Standing leaf area index (unit of leaf area per unit of ground area; total one-sided) & $\mathrm{m}^{2} \mathrm{~m}^{-2}$ \\
\hline FALL & Indicator variable for season of foliage sampling ( 1 if fall, 0 otherwise) & - \\
\hline $\mathrm{RD}_{\mathrm{DF}}$ & Douglas-fir relative density & $\mathrm{m}^{2}$ ha $\sqrt{\mathrm{cm}^{-1}}$ \\
\hline SINA & Sine transformation of aspect $[\sin (2 \times \pi \times$ ASPECT $/ 360)]$ & - \\
\hline SLA & Litterfall specific leaf area & $\mathrm{cm}^{2} \mathrm{~g}^{-1}$ \\
\hline TPH & Total number of trees per ha & - \\
\hline LITTER $_{W D}$ & Annual fine woody litterfall & $\mathrm{kg} \mathrm{ha}^{-1}$ \\
\hline
\end{tabular}

\subsection{Data collection}

\subsubsection{Plot measurements}

A series of permanent plots was used in this study to scale tree leaf area to the stand-level and to relate stand attributes to LAI and foliage litterfall. A total of 26 young plantations (10-30 years of age) and 10 older plantations (30-60 years of age) were sampled. SNC severity in each young plantation has been recorded every year since 1996 by the Oregon Department of Forestry. Square 0.08-ha permanent plots were established in spring of 1998, and all trees were tagged at breast height and measured for DBH, HT, and height to crown base (HCB). These measurements were repeated in the spring of 2000, 2002, and 2004. Ten dominant or codominant trees on each plot have been scored for SNC every year. Each crown was divided vertically into thirds, the average number of years that foliage was retained in each third was estimated visually to the nearest 0.1 year, and tree average was computed as a simple mean. Overall crown discoloration was rated on a 1 to 4 scale with 1 being highly discolored. Plot ratings were computed as the average of all ten trees.

For the older plantations, two square 0.2-ha permanent plots (control + thinned) were established within each stand during the spring of 2001 and all trees were tagged at breast height and measured for DBH, HT, and HCB. These measurements were repeated in spring 2003. Five trees on each plot have been scored for SNC every year starting in 2001. Due to the heights of crowns and associated visibility problems in these older, larger trees, a single average rating was given for the whole crown. Sapwood width was measured on two breast-height cores taken perpendicular to slope. Sapwood area at crown base was estimated from a previously constructed sapwood taper equation for Douglas-fir [35]. Application of this regional sapwood taper equation has been shown to give little prediction bias for north coastal Oregon regardless of SNC severity [64]. Crown sparseness (CLSA) was computed as the ratio of crown length $(\mathrm{CL} ; \mathrm{cm})$ to sapwood area at crown base $\left(\mathrm{cm}^{2}\right)$. Plot ratings were computed as the average of all five trees.

\subsubsection{Leaf area index}

Foliage was sampled from the $10-30$-y-old plantations prior to budbreak in 2002 and in the fall of 2002, and from the 30-60-y-old plantations in the winter of 2004. Before felling 3-5 sample trees in each stand, diameter at breast height (DBH), total height (HT), height to crown base (HCB), and maximum crown width $(\mathrm{CW})$ were measured (Tab. II). After felling, the height and diameter of every living branch ( $>1 \mathrm{~mm}$ in diameter) were recorded, and 3-5 branches were randomly selected in each third of the crown, including 2-3 whorl branches and 1-2 interwhorl branches. Each sample branch was cut flush with the bole and transported back to the laboratory, clipped into separate age classes, and oven-dried at $85^{\circ} \mathrm{C}$ for three days. Before drying, a subsample of fresh foliage from each age class was frozen for later assessment of specific leaf area (SLA; $\left.\mathrm{cm}^{2} \mathrm{~g}^{-1}\right)$. Foliage was separated from woody material in the dried branch segments, and each component was weighed to the nearest $0.01 \mathrm{~g}$.

Fifty to 100 needles from each frozen subsample were measured for projected leaf area (nearest $0.001 \mathrm{~cm}^{2}$ ) by an image analysis system (CID corporation, Longview, WA). After measurement, the needles were dried at $80{ }^{\circ} \mathrm{C}$ for $48 \mathrm{~h}$ and weighed to the nearest $0.001 \mathrm{~g}$. Specific leaf area was calculated as the ratio of total projected leaf 
Table II. Attributes of the stands sampled for LAI and litterfall.

\begin{tabular}{|c|c|c|c|c|}
\hline Attribute & Mean & Standard deviation & Minimum & Maximum \\
\hline \multicolumn{5}{|c|}{ Direct LAI determination $(n=36)$} \\
\hline Total basal area $\left(\mathrm{m}^{2} \mathrm{ha}^{-1}\right)$ & 37.89 & 15.39 & 10.45 & 76.83 \\
\hline Douglas-fir quadratic mean diameter $(\mathrm{cm})$ & 29.95 & 10.66 & 11.41 & 53.49 \\
\hline Trees per ha & 663.33 & 372.69 & 175.00 & 1790.75 \\
\hline Average breast-height age (year) & 28.82 & 13.97 & 11.00 & 60.70 \\
\hline Site index (Bruce (1981); height at 50 years breast height, in m) & 39.39 & 4.15 & 26.63 & 46.20 \\
\hline $\mathrm{LAI}\left(\mathrm{m}^{2} \mathrm{~m}^{-2}\right.$; one-sided $)$ & 5.45 & 2.16 & 2.28 & 11.24 \\
\hline Foliage retention (years) & 2.58 & 0.81 & 1.56 & 4.39 \\
\hline \multicolumn{5}{|c|}{ Litterfall dynamics $(n=15)$} \\
\hline Total basal area $\left(\mathrm{m}^{2} \mathrm{ha}^{-1}\right)$ & 35.87 & 9.12 & 21.29 & 49.18 \\
\hline Douglas-fir quadratic mean diameter $(\mathrm{cm})$ & 28.73 & 4.08 & 21.70 & 37.68 \\
\hline Trees per ha & 668.14 & 267.33 & 271.70 & 1235.00 \\
\hline Average breast-height age (year) & 24.56 & 2.75 & 18.30 & 29.80 \\
\hline Site index ([10]; height at 50 years breast height, in $\mathrm{m}$ ) & 39.29 & 1.51 & 37.51 & 41.16 \\
\hline $\mathrm{LAI}\left(\mathrm{m}^{2} \mathrm{~m}^{-2} ;\right.$ one-sided $)$ & 5.33 & 1.28 & 3.85 & 8.45 \\
\hline Foliage retention (years) & 2.32 & 0.47 & 1.66 & 3.85 \\
\hline
\end{tabular}

area to total dry weight of the sample. Branch foliage mass was converted to foliage area with the SLA from each age class, and branch foliage area was then scaled to the tree level by estimating foliage area on each live branch (see Sect. 2.3 Data analysis).

\subsubsection{Litterfall}

To assess monthly and annual foliage dynamics, twelve relatively young (10-30-y in age) stands were intensively sampled for litterfall. Within each 0.08 -ha plot, ten square $0.18 \mathrm{~m}^{2}$ litter traps were systematically placed $3 \mathrm{~m}$ apart and $3 \mathrm{~m}$ from the plot edge. The traps were established in April 2002 and were collected monthly for the first year and at least three times a year over the next two years. A subsample of Douglas-fir litter was set aside at each collection date to estimate specific leaf area. The remaining litter was dried at $85{ }^{\circ} \mathrm{C}$ for $48 \mathrm{~h}$ and separated into several different components including: (1) Douglasfir foliage; (2) Douglas-fir woody material; (3) hardwood foliage; (4) western hemlock and other conifer foliage; and (5) other materials such as fruits, bud scales, and cones. Each component was weighed to the nearest $0.01 \mathrm{~g}$ and Douglas-fir foliage mass was converted to one-sided area using the SLA estimated for that sampling date.

\subsection{Data analysis}

Various linear and nonlinear regression models were fitted to the data to estimate stand-level LAI and foliage dynamics. Foliage was sampled hierarchically (branches within trees within plots within years), so violated the assumption of independence and zero correlation. Analyses were therefore performed with multi-level, mixedeffects models, and nested model forms were compared with likelihood ratio tests. When residual analysis indicated heteroskedasticity, observations were weighted by a power variance function of the primary independent variable. Final models were chosen on the basis of residual analysis, Akaike's information criterion (AIC) and biological interpretability. All analyses were done in SAS v8.2 (SAS Institute, Cary, NC, USA) and S-PLUS v6.2 (Mathsoft, Seattle, WA, USA).

\subsubsection{Leaf area index}

Branch-level foliage area was estimated for each branch on the felled sample trees as a plot-specific function of branch diameter and height in the crown [66]. Tree-level foliage area was then computed as the sum of individual branch foliage areas. Total leaf area $\left(\mathrm{m}^{2}\right)$ for each tree on the sample plots was estimated by fitting a global model to the entire dataset, extracting random coefficient for each plot, and modifying parameter estimates to yield a plot-specific equation [49]. The best model was similar in form to that presented by Maguire and Bennett [36]:

$$
\mathrm{TLA}=\beta_{11} \cdot \mathrm{CL}^{\beta_{12}+\delta_{11}+\phi_{11}} \cdot \exp \left[\left(\beta_{13}+\delta_{12}+\phi_{12}\right) \cdot \frac{\mathrm{DBH}}{\mathrm{HT}}\right]+\varepsilon_{1}
$$

where TLA is tree leaf area $\left(\mathrm{m}^{2}\right)$, the $\beta_{1 \mathrm{i}} \mathrm{s}$ are parameters to be estimated from the data, the $\delta_{\mathrm{i}}$ are random year effects $(i=1$ or 2$)$ with $\delta_{\mathrm{i}} \sim \mathrm{N}\left(0, \sigma_{\delta \mathrm{i}}^{2}\right)$, the $\phi_{\mathrm{i}}$ are random plot effects $\phi_{\mathrm{i}} \sim \mathrm{N}\left(0, \sigma_{\phi \mathrm{i}}^{2}\right)$, and $\varepsilon_{1}$ is a random disturbance with $\varepsilon_{1} \sim \mathrm{N}\left(0, \sigma_{\varepsilon 1}^{2}\right)$. LAI was calculated by summing the predicted tree leaf areas for each plot and dividing by the plot area.

The pattern in LAI among the sampled stands was described by the following model:

$$
\begin{aligned}
\mathrm{LAI}= & \exp \left(\beta_{20}+\delta_{20}+\Phi_{20}+\beta_{21} \mathrm{TPH}+\beta_{22} \mathrm{RD}_{\mathrm{DF}}+\beta_{23} \mathrm{AGE}+\right. \\
& \left.\beta_{24} \mathrm{CLSA}_{\mathrm{PLOT}}+\beta_{25} \mathrm{FOLRET}+\beta_{26} \mathrm{FALL}\right)+\varepsilon_{2}
\end{aligned}
$$

where TPH is stems per ha, $\mathrm{RD}_{\mathrm{DF}}$ is Douglas-fir relative density [12], AGE is mean breast-height age, CLSA [37], FOLRET is mean foliage retention (years), FALL is an indicator variable for sampling season ( 1 if foliage was sampled in fall of 2002, 0 otherwise), the $\beta_{2 \mathrm{i}} \mathrm{s}$ are parameters to be estimated from the data, and $\varepsilon_{2}$ is a random disturbance with $\varepsilon_{2} \sim \mathrm{N}\left(0, \sigma_{2}^{2}\right)$. The variable FALL was included because LAI would be theoretically higher during this time period because current-year foliage is completely developed, while the period of heavy foliage litterfall is only starting. Preliminary analysis suggested this variable worked as well or better than Julian date. 


\subsubsection{Litterfall}

\subsubsection{Litter specific leaf area}

The amount of Douglas-fir foliage litterfall was calculated during each collection period as the average dry weight of all ten traps divided by trap area $\left(0.18 \mathrm{~m}^{2}\right)$. Foliage litterfall was converted to onesided leaf area by multiplying dry weight by SLA. For periods with a missing a SLA measurement, the plot mean SLA over all collection periods was used.

The change in litter SLA provides insight into the intensity of translocation from senescing foliage, as well as decay rates of foliage litter that has remained on the forest floor for a period. The effects of SNC on average litter SLA and its seasonal change were described as a linear function of several stand variables:

$$
\begin{gathered}
\text { SLA }=\beta_{30}+\phi_{30}+\beta_{31} \mathrm{BA}+\beta_{32} \times \text { ASP } 12+\beta_{33} \times \text { COAST }+ \\
\beta_{34} \times \text { FOLRET }+\beta_{35} \times \text { JDATE } \beta_{36} \times \ln (\mathrm{JDATE})+ \\
\beta_{37} \times(\mathrm{COAST} \times \mathrm{FOLRET})+\varepsilon_{3}
\end{gathered}
$$

where BA is stand basal area $\left(\mathrm{m}^{2} \mathrm{ha}^{-1}\right)$, ASP12 is cosine transformation of slope and aspect [53], COAST is the plot distance from the Pacific Ocean $(\mathrm{km})$, JDATE is Julian date, the $\beta_{3 \mathrm{i}} \mathrm{s}$ are parameters to be estimated from the data, and $\varepsilon_{3}$ is a random disturbance with $\varepsilon_{3} \sim \mathrm{N}\left(0, \sigma_{3}^{2}\right)$.

\subsubsection{Annual litterfall}

Total annual litterfall consisting of Douglas-fir foliage was described by the following model:

$$
\begin{gathered}
\text { LITTER }_{\mathrm{FOL}}=\exp \left(\beta_{40}+\delta_{40}+\phi_{40}+\beta_{41} \mathrm{AGE}+\beta_{42} \mathrm{DQ}_{\mathrm{DF}}+\beta_{43}\right. \text { SINA+ } \\
\left.\beta_{44} \mathrm{ASP} 22+\beta_{45} \text { FOLRET }+\beta_{46} \mathrm{CLSA}_{\mathrm{PLOT}}\right)+\varepsilon_{4}
\end{gathered}
$$

where LITTER FOL $_{\text {is }}$ the annual litterfall of Douglas-fir foliage $\left(\mathrm{m}^{2} \mathrm{~m}^{-2}\right), \mathrm{DQ}_{\mathrm{DF}}$ is Douglas-fir quadratic mean diameter $(\mathrm{cm})$, SINA is the sine transformation of aspect [53], ASP22 is the sine transformation of slope and aspect [53], the $\beta_{4 \mathrm{i}} \mathrm{s}$ are parameters to be estimated from the data, and $\varepsilon_{4}$ is a random disturbance with $\varepsilon_{4} \sim \mathrm{N}\left(0, \sigma_{4}^{2}\right)$.

The relationship between annual litterfall of fine woody material and several stand-level variables was also described by regression analysis. The final model had the following form:

$$
\begin{aligned}
\text { LITTER }_{\mathrm{WD}}= & \beta_{50}+\phi_{50}+\delta_{50}+\beta_{51} \mathrm{AGE}+\beta_{52} \mathrm{TPH}+\beta_{53} \mathrm{COSA}+ \\
& \beta_{54} \mathrm{FOLRET}+\beta_{55} \mathrm{CLSA}_{\mathrm{PLOT}}+\varepsilon_{5}
\end{aligned}
$$

where LITTER $\mathrm{WD}_{\text {is }}$ annual fine woody litterfall $\left(\mathrm{kgha}^{-1}\right)$, TPH is defined above, COSA is the cosine transformation of aspect [53], the $\beta_{5 \mathrm{i}} \mathrm{s}$ are parameters to be estimated from the data, and $\varepsilon_{5}$ is a random disturbance with $\varepsilon_{5} \sim \mathrm{N}\left(0, \sigma_{5}^{2}\right)$.

\subsubsection{Seasonal distribution}

To evaluate the seasonal trend in foliage loss, a model was developed to describe the foliage loss in terms of the proportion of total foliage area held by the stand at time of bud break. Date of first bud flush was estimated for each plot by generating its daily climate in Daymet (http://www.daymet.org), and then applying techniques described by Thomson and Moncrieff [55]. For each litterfall collection date, the number of days and cumulative foliage loss since bud flush

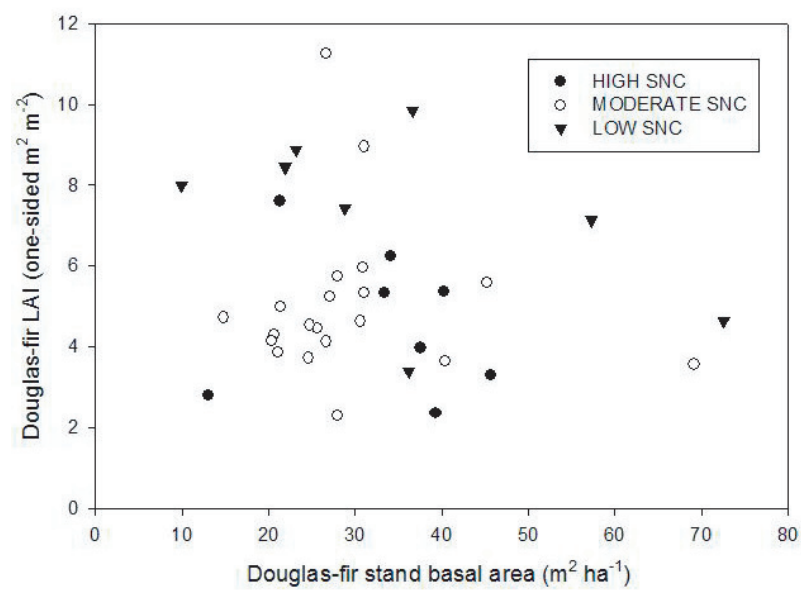

Figure 1. Plot of Douglas-fir LAI (one-sided $\mathrm{m}^{2} \mathrm{~m}^{-2}$ ) versus Douglas-fir stand basal area $\left(\mathrm{m}^{2} \mathrm{ha}^{-1}\right)$ by SNC severity class. SNC is considered to be high on plots with mean foliage retention less than 2 years, and low on plots with mean foliage retention greater than 3 .

were calculated. The following equation was fitted to the resulting data: final model had the following form:

$$
\begin{aligned}
& \mathrm{CM}_{-} \% \mathrm{FOL}=\frac{1}{1+\exp \left(\beta_{60}+\phi_{60}+\beta_{61} \mathrm{DSBF}+\beta_{62} \times \mathrm{ELEV}+\right.}+\varepsilon_{6} \\
& \left.\beta_{63} \mathrm{COSA}+\beta_{64} \mathrm{CLSA}_{\text {PLOT }}\right)
\end{aligned}
$$

where CM_\%FOL is the cumulative foliage litterfall as a proportion of the leaf area held on the day of budbreak, DSBF is the number of days since bud flush, ELEV is elevation above sea level (m), the $\beta_{6 \mathrm{i}} \mathrm{S}$ are parameters to be estimated from the data, and $\varepsilon_{6}$ is a random disturbance with $\varepsilon_{6} \sim \mathrm{N}\left(0, \sigma_{6}^{2}\right)$.

The seasonal distribution of fine woody litterfall was described by a similar model:

$$
\mathrm{CM}_{-} \% \mathrm{WD}=\frac{1}{1+\exp \left(\beta_{70}+\phi_{70}+\beta_{71} \mathrm{DSBF}+\beta_{72} \times \mathrm{ELEV}+\beta_{73} \mathrm{SINA}\right.}+\varepsilon_{7}
$$

where CM_\%WD is cumulative fine woody litterfall as a proportion of fine woody material initially held by the stand on the day of budbreak, the $\beta_{7 \mathrm{i}} \mathrm{s}$ are parameters to be estimated from the data, and $\varepsilon_{7}$ is a random disturbance with $\varepsilon_{7} \sim \mathrm{N}\left(0, \sigma_{7}^{2}\right)$.

\section{RESULTS}

\subsection{Leaf area index}

Douglas-fir LAI ranged from 2.29 to 11.25 , averaging 5.44 with a standard deviation of 2.16 (Fig. 1). Within-year variability comprised nearly $67 \%$ of the original variation in LAI, and was significantly greater than between-year variability. Model [2] containing both CLSAPLOT and foliage retention did not perform significantly better than one containing just foliage retention $(p=0.127)$. Although various transformations of Julian date were explored to account for date of LAI estimation, none provided a better fit to the data than the 
Table III. Final equation form, $\mathrm{R}^{2}$, and residual standard error (RSE) for equations presented in this study.

\begin{tabular}{|c|c|c|c|}
\hline Model & Equation form & $R^{2}$ & $R S E$ \\
\hline 2 & $\begin{aligned} \mathrm{LAI}= & \exp \left(1.3619-0.0003 \times \mathrm{TPH}+0.1134 \times \mathrm{RD}_{\mathrm{DF}}\right. \\
& -0.0241 \times \mathrm{AGE}+0.1706 \times \mathrm{FOLRET}+0.3103 \times \mathrm{FALL})\end{aligned}$ & 0.78 & 1.23 \\
\hline 3 & $\begin{aligned} \mathrm{SLA}= & 4.4244-0.0045 \times \mathrm{BA}+0.0924 \times \text { ASP } 12-0.0067 \times \mathrm{COAST} \\
& +0.0005 \times \mathrm{JDATE}-0.0491 \times \ln (\mathrm{JDATE})\end{aligned}$ & 0.29 & 0.08 \\
\hline 4 & $\begin{aligned} \text { LITTER }_{\mathrm{FOL}}= & \exp \left(2.4851-0.1096 \times \mathrm{AGE}+0.0472 \times \mathrm{DQ}_{\mathrm{DF}}+0.1997 \times \mathrm{SINA}\right. \\
& +0.3106 \times \mathrm{ASP} 22-0.3589 \times \mathrm{FOLRET})\end{aligned}$ & 0.45 & 0.01 \\
\hline 5 & $\begin{aligned} \ln \left(\text { LITTER }_{\mathrm{WD}}\right)= & 6.0369+0.0422 \times \mathrm{AGE}+0.0005 \times \mathrm{TPH} \\
& -0.0474 \times \mathrm{COSA}-0.5043 \times \text { FOLRET }\end{aligned}$ & 0.32 & 0.55 \\
\hline 6 & $\begin{array}{c}\text { CM_\% FOL }=\frac{1}{1+\exp (4.0716-0.0214 \times \mathrm{DSBF}-0.2508 \times \mathrm{ELEV}} \\
\left.-0.0086 \times \mathrm{COSA}-0.1093 \times \mathrm{CLSA}_{\mathrm{PLOT}}\right)\end{array}$ & 0.96 & 0.07 \\
\hline 7 & $\begin{array}{c}\text { CM_\% WD = } \frac{1}{1+\exp (8.3929-0.0234 \times \text { DSBF }-0.0209 \times \text { ELEV }+3.3041 \times \text { SINA }} \\
-0.9428 \times \text { FOLRET }-1.2030 \times(\text { SINA } \times \text { FOLRET }))\end{array}$ & 0.93 & 0.09 \\
\hline
\end{tabular}

single indicator variable for fall sampling. Overall, LAI significantly increased with $\operatorname{RD}_{\mathrm{DF}}(p<0.0001)$ and FOLRET $(p<0.0001)$, while it decreased with $\mathrm{TPH}_{\mathrm{DF}}(p=0.045)$ and AGE $(p<0.0001$; Tab. III). Although a random parameter for year significantly improved model fit $(p=0.0104)$, there was very little variation between years after accounting for season of sampling (FALL), stand structure $\left(\mathrm{RD}_{\mathrm{DF}}, \mathrm{TPH}_{\mathrm{DF}}, \mathrm{AGE}\right)$, and SNC severity $(\sim 1 \%)$.

For a given stand structure and year, LAI in a stand with severe SNC (FOLRET $=1.5$ ) was reduced by $31 \%$ when compared to a stand with little SNC (FOLRET = 3.5). On average, LAI estimates were $36 \%$ higher in the fall than in spring of the same year. LAI estimated by sampling branches in the spring just prior to bud break did not differ significantly from LAI estimated by early winter sampling ( $p=0.5639)$.

\subsection{Litterfall}

\subsubsection{Litter specific leaf area}

Litterfall SLA averaged $56.8 \pm 5.13 \mathrm{~cm}^{2} \mathrm{~g}^{-1}$ and ranged from 47.4 to $77.6 \mathrm{~cm}^{2} \mathrm{~g}^{-1}$. Litterfall SLA increased as plots became steeper and more southerly $(p<0.0001)$, while it decreased with distance from the coast $(p<0.0001)$. SNC severity and its interaction with distance from the coast were not significant, most likely because SNC severity has been shown to increase on southern aspects [40] and decrease with distance from the coast [50]; hence, the marginal effect of SNC was not significant. Litterfall SLA changes systematically with Julian date $(p=0.0002)$, with a minimum in late March/early April and a maximum in December. The known correlations between SNC severity and slope, aspect, and distance from coast suggested that litterfall SLA increased with increasing SNC severity (Fig. 2).

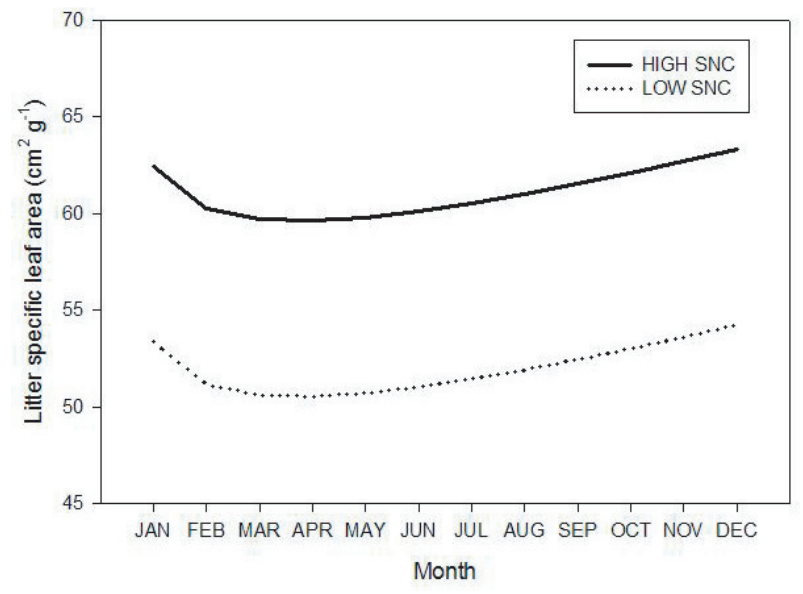

Figure 2. Predicted litter specific leaf area $\left(\mathrm{cm}^{2} \mathrm{~g}^{-1}\right)$ by month and SNC severity. Stands growing on a southerly aspect and $5 \mathrm{~km}$ from the coast were assumed to have high SNC severity, and those growing on a northeasterly aspect and $25 \mathrm{~km}$ from the coast were assumed to have low SNC severity.

\subsubsection{Annual litterfall}

Mean annual foliage litterfall was $1.44 \pm 0.46 \mathrm{~m}^{2} \mathrm{~m}^{-2}$ and ranged from 0.52 to 2.75 . Expressed as a proportion of the leaf area held by the stand at bud break, annual foliage litterfall averaged $0.34 \pm 0.10$ and ranged from 0.13 to 0.53 (Fig. 3). Unlike estimates of LAI, the within-year variability of annual foliage litterfall was nearly equal to the betweenyear variability. Foliage litterfall differed significantly among years $(p<0.0001)$, with the greatest in 2002. Between year differences in total foliage litterfall for a given stand structure and SNC severity averaged $0.3 \pm 0.2 \mathrm{~m}^{2} \mathrm{~m}^{-2}$ and was as high as 0.5 . Foliage litterfall increased significantly with Douglas-fir 


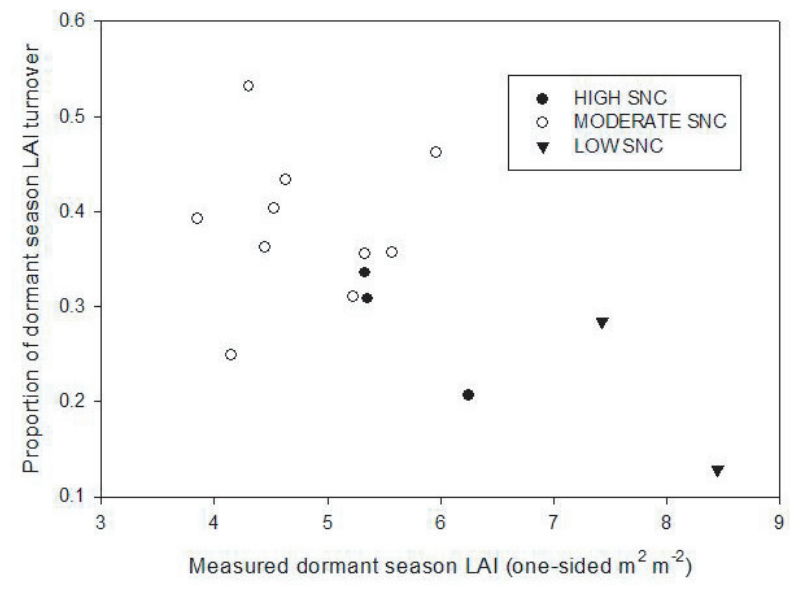

Figure 3. Annual Douglas-fir LAI (one-sided $\mathrm{m}^{2} \mathrm{~m}^{-2}$ ) versus Douglas-fir stand basal area $\left(\mathrm{m}^{2} \mathrm{ha}^{-1}\right)$ by SNC severity class.

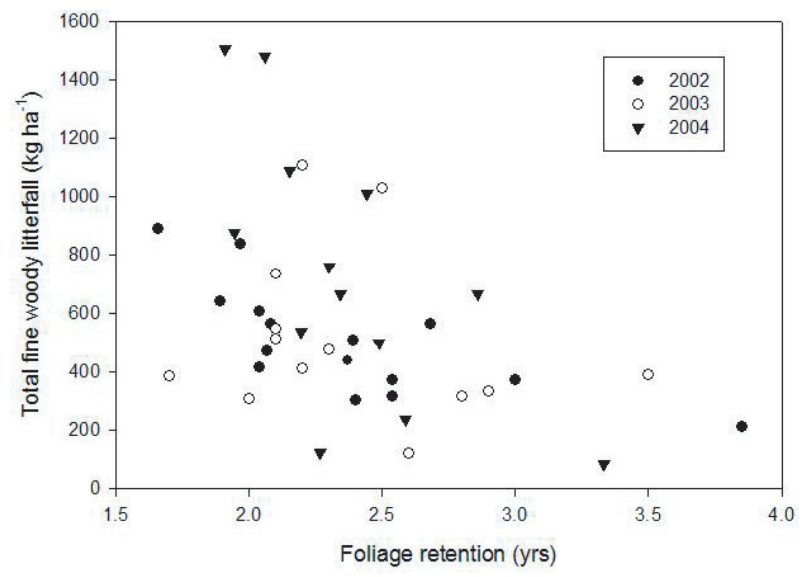

Figure 4. Annual Douglas-fir fine woody litterfall $\left(\mathrm{kg} \mathrm{ha}^{-1}\right)$ versus foliage retention for 2002, 2003, and 2004.

quadratic mean diameter $(p<0.0001)$ and a more northeasterly aspect $(p<0.0001)$, while it decreased with breast-height age $(p<0.0001)$ and foliage retention $(p<0.0001)$. For a given year and stand structure, a stand with low SNC severity $($ FOLRET $=3.5)$ had $51 \%$ lower foliage litterfall than a stand with high SNC severity $($ FOLRET $=1.5)$.

Annual fine woody litterfall was $578.4 \pm 333.6 \mathrm{~kg} \mathrm{ha}^{-1}$ and ranged from 84.4 to $1505.0 \mathrm{~kg} \mathrm{ha}^{-1}$ (Fig. 4). In comparison to foliage litterfall, annual variation in fine woody litterfall was minimal. Fine woody litterfall did differ significantly between years $(p=0.0285)$, with $39 \%$ greater litterfall in 2004 than in 2002. Fine woody litterfall increased significantly with breast height age ( $p=0.0256)$, the number of stems per ha ( $p=$ $0.0043)$, and a more northeasterly aspect $(p=0.0060)$, while it decreased with foliage retention $(p=0.0069)$. For a given stand structure, fine woody litterfall was $45 \%$ lower in a stand with low SNC when compared to one with severe SNC.

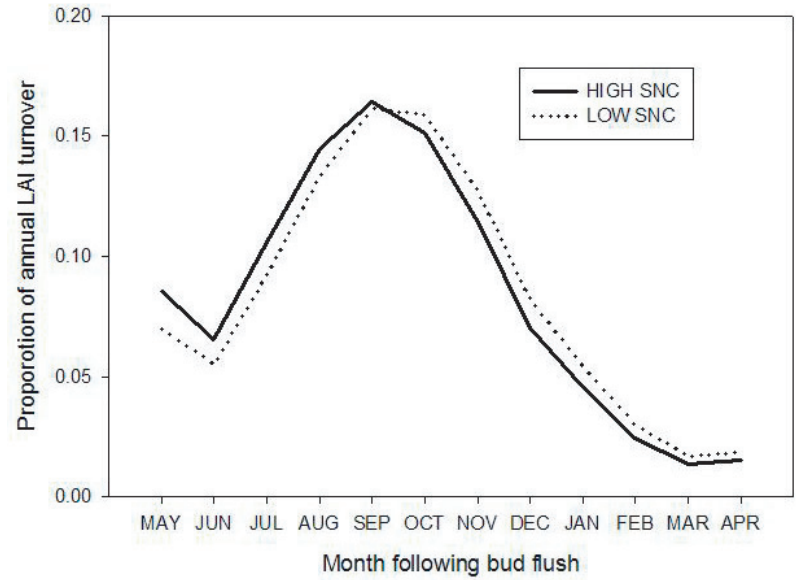

Figure 5. Seasonal distribution of foliage litterfall as a proportion of total leaf area held by the stand on the date of bud break (Eq. (6)). Date of bud break was assumed to be May 1. CLSAPLOT was assumed to be 7.5 and 5.5 for high and low SNC severity, respectively.

\subsection{Seasonal distribution}

Foliage litterfall peaked in the early fall, regardless of SNC level. On average, nearly $50 \%$ of foliage litterfall occurred between October and December. A secondary peak in foliage litterfall occurred in the spring, and it peaked sooner after bud flush as the stand elevation increased $(p<0.0001)$, the aspect became more northerly $(p<0.0001)$, and SNC severity increased ( $p=0.0048$ ) (Fig. 5).

Fine woody litterfall also showed a seasonal trend, peaking in the late fall to early winter regardless of SNC level. Nearly $52 \%$ of fine woody litterfall occurred between December and February. SNC had a significant influence on the seasonal distribution of fine woody litterfall as indicated by foliage retention $(p<0.0001)$, but the relationship was also influenced significantly by plot aspect ( $p<0.0001)$. On northern aspects, fine woody litterfall peaked earlier as SNC severity decreased and plot elevation increased ( $p<0.0001)$. On southern aspects, there was relatively little difference in the seasonal distribution of fine woody litterfall among stands with varying SNC severity or elevation (Fig. 6).

\section{DISCUSSION}

SNC has dramatically lowered Douglas-fir LAI and changed the total amount and seasonal distribution of foliage litterfall in plantations of north coastal Oregon. LAI in this study averaged approximately 5.5, but LAI in some stands can be reduced as much as $31 \%$ by SNC. Litterfall rates were more variable than LAI, but foliage and fine woody litterfall were nearly 52 and $45 \%$ greater, respectively, in stands with severe $\mathrm{SNC}$. A greater proportion of the foliage litter also falls earlier in the growing season with increasing SNC severity. In contrast, fine woody litterfall did not differ much among sites with varying SNC intensity on southern aspects. On northern 

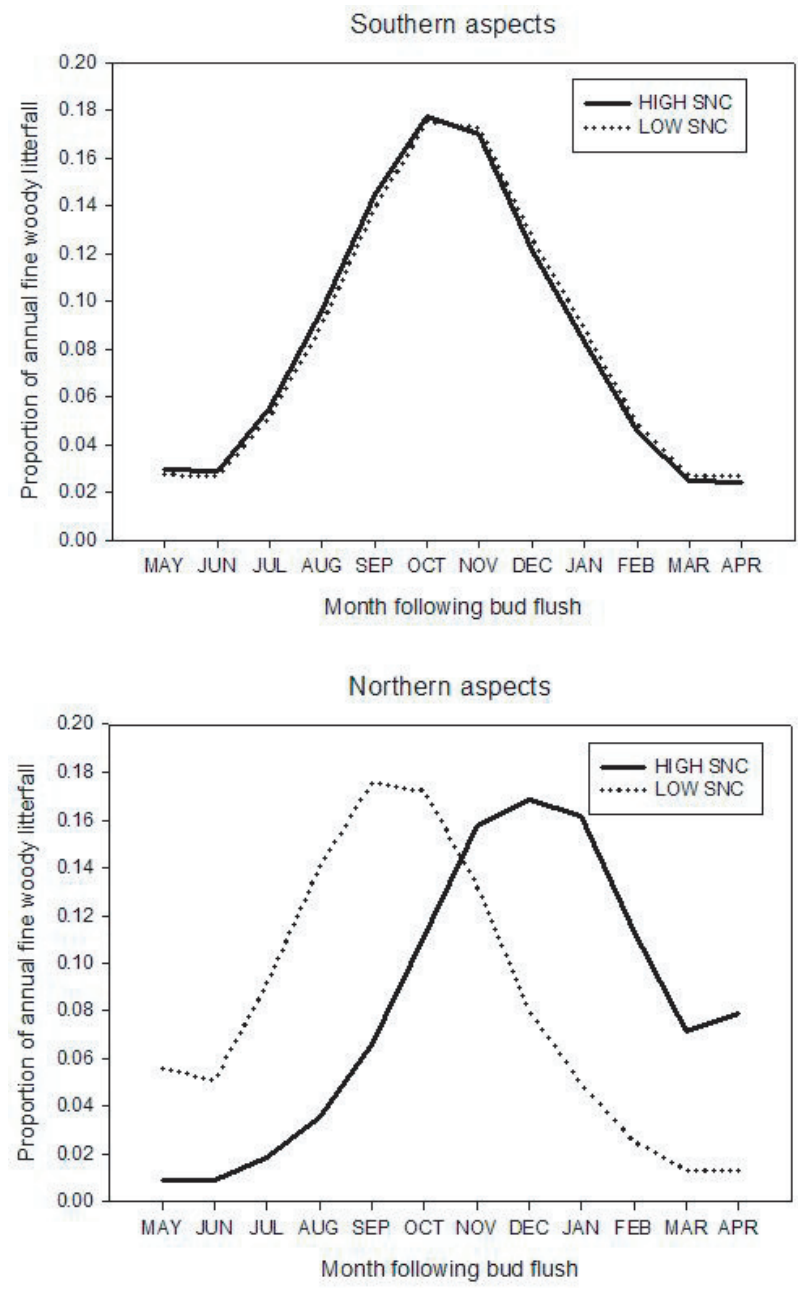

Figure 6. Seasonal distribution of fine woody litterfall as a proportion of fine woody material initially held by the stand on the date of bud break (Eq. (7)): (a) southerly aspect and (b) northerly aspect.

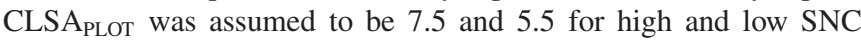
severity, respectively.

aspects, peak rate occurred later in the growing season for sites with high SNC.

Changes in litterfall patterns have important implications for nutrient-cycling and future productivity of these plantations. Defoliation by insects and disease is a highly dynamic and variable process that can significantly modify several critical ecosystem processes and conditions such as decomposition rates [11], susceptibility to further disturbance [42], and soil temperature and moisture levels [26]. These changes are driven by the loss of foliage from the canopy and by accelerated addition of relatively high-quality litter to the forest floor. Quantification of these fluxes should therefore lead to a better understanding of tree and stand responses and increase our capacity to predict the economic and ecological consequences of diseases like SNC. However, estimating LAI and the turnover rate of foliage contributing to LAI even under healthy conditions is challenging given the inherent annual and seasonal variation in development of new foliage and loss of older foliage.

\subsection{Leaf area index}

LAI has been shown to increase with enhanced nutrition [3], greater water availability [20], increased age (up to a steady-state at 5 to $20 \mathrm{y}$; [29]), and greater stand basal area [17]. Turner and Long [59], however, reported that Douglasfir stands do not reach an LAI plateau until age 40-60 y. LAI in this study increased with Douglas-fir stand relative density, but decreased with both trees per ha and mean breast-height age. The difference in stand structure between two stands with the same relative density but differing trees per ha may account in part for the greater LAI with fewer trees per ha. The longer crowns with fewer trees per hectare will cause a very different pattern in light extinction, so under this condition it may be possible to display more foliage that receives light above the compensation point. The decline in LAI with age may fit with the proposed peak at 5-20 years because mean breastheight age averaged 29 and ranged from 11 to 61 . It must be kept in mind, however, that many of the trends observed in unmanaged stands are complicated by aggressive density management in most of the sampled Douglas-fir plantations. The decline in LAI may reflect the varied management history of these stands, as more than half received a pre-commercial thinning treatment of varying intensity.

Mean LAI was 5.5 in this study, a value much lower than previously published for Douglas-fir. The mean reduction in LAI due to SNC was $1.9 \mathrm{~m}^{2} \mathrm{~m}^{-2}$. Similar, but less drastic, reductions in stand LAI have also been reported in response to climatic disturbances such as wind and ice storms [19,54]. LAI has generally ranged between 4.0 and 11.0 in Douglasfir, with a mean around $7.5[41,54,58]$; however, previous estimates have been made mostly in old-growth or unmanaged Douglas-fir stands. Also, most of the Pacific Northwest studies estimated LAI using optical techniques that have been shown to consistently underestimate LAI, in part because needles within crowns and crowns within canopies are more aggregated than the random distribution typically assumed in applications of Beer's law [41], and because differences in the ratio of photosynthetic to non-photosynthetic surface area are not accommodated. Estimated LAIs, however, were close to levels reported in other young Douglas-fir plantations that had been intensively managed [60]. The $36 \%$ difference in LAI estimated in early spring vs. late summer was a larger relative difference than previously found in Douglas-fir and other coniferous species $[6,63,69]$.

\subsection{Litterfall}

\subsubsection{Size}

Few studies have reported the SLA of needles in foliage litter, or the seasonal variation in litter SLA [48]. The SLA of freshly senescent foliage relative to live foliage from younger 
age classes gives some indication of the translocation of mobile elements. The further decline in SLA once it arrives at the forest floor similarly indicates the degree of decomposition [30]. Litter SLA is usually very similar in many respects to that of live foliage [48], but has a definite seasonal pattern associated with formation of new foliage, gradual senescence of old foliage, and associated translocation patterns within the canopy [45]. Roberts et al. [48] and Bouriaud et al. [7] found a wide range of litter SLA throughout the year, but SLA was generally highest in the early fall due to the larger contribution of foliage from the bottom of the canopy. As the year progresses, foliage with smaller SLA from the upper canopy contributed substantially more to the foliage litterfall [48]. Piene and Fleming [45] found that rates of needlefall increased for successively older needle age classes.

Although no direct measures of SNC severity were significantly related to litter SLA, the combination of slope, aspect, and distance from the coast suggest that litter SLA increased with greater SNC severity. SNC has imposed a higher foliage turnover rate, a greater proportion of foliage in younger age classes, and greater average SLA [65]. Higher SLA is attributable to flatter and/or less dense needles, and this SNC effect is passed on as a greater SLA in foliage litter. The positive correlation between future rate of litter decomposition and litter SLA [30] suggests that decomposition may increase with greater SNC severity, especially when considering the compounding effects of foliage loss on forest floor temperature and moisture. In short, tree responses to the fungus causing SNC have many important implications for ecosystem processes like nutrient-cycling.

\subsubsection{Amount}

Total litter production has been shown to increase with age due to the increasing input of fine and coarse woody material, despite relatively constant foliage litterfall after age 40 [16] Several factors besides age influence litterfall rates, including stand spacing [45], site quality [34], species composition, and latitude [1]. Climate plays a particularly important role, as suggested by a strong positive correlation between needle litterfall and mean July temperature in Pinus sylvestris [27]. Conversely, unseasonably low fall temperatures nearly tripled the amount of Douglas-fir litter that was dropped during the ensuing year [13]. Year to year variability in litterfall therefore appears to follow a consistent pattern among many forest types and locations.

Foliage litterfall increased with Douglas-fir quadratic mean diameter in this study, but decreased with age, suggesting that litterfall was greater at wider spacing or lower stand densities. In Abies balsamea, Piene and Fleming [45] also found that spacing affected the timing and annual variation in foliage litterfall. However, unspaced or higher density plots had significantly lower needle lifespans, implying greater needlefall rates if LAI was equal among spacings. Trofymow et al. [56] and Turnbull and Madden [57] similarly found a positive correlation between litterfall rates and stand basal area, although Trofymow et al. [56] noted that litterfall rates correlated poorly with stand density index. In stands that are still building leaf area after a recent thinning, foliage litterfall rates should be lower, suggesting that the relationship between stand density and needlefall in thinning and spacing studies can be confounded with the dynamics of LAI.

Litterfall should also be greater in stands with more rapid height growth, because the canopy of more or less fixed foliage area is moving upward more rapidly. The lower litterfall with increasing stand age in this study may be a result of decelerating height growth over the sampled age range ( 10-30 y.). The influence of aspect on litterfall rates has not been previously described, but could also be driven by associated differences in height growth. Other studies have found a positive correlation between stemwood increment and litterfall rates $[56,57]$. However, foliage litterfall decreased as aspect became more northeasterly despite an expectation of lower water stress and more rapid growth. In this study, however, aspect is confounded with SNC severity as indicated by higher fungal colonization and more severe SNC symptoms reported by Manter et al. [40] for south slopes.

Bray and Gorham [8] noted that, in general, leaf material contributed $60-76 \%$ of annual litterfall, while branches comprised $12-15 \%$. For the most part, litterfall composition in this study fell within these ranges. However, plots with higher level of foliage retention tended to have a greater proportion of foliage in their litterfall because crown recession (branch mortality) was slower than on plots with low foliage retention [65]. Fogel and Hunt [15] reported that total litterfall was $2680 \mathrm{~kg} \mathrm{ha}^{-1}$ in a 43-year-old Douglas-fir stand on the east side of the Oregon Coast Range, and that almost 90\% was foliage. Gessel and Turner [16] found that total annual litterfall ranged from 1300 to $6138 \mathrm{~kg} \mathrm{ha}^{-1}$ in Douglas-fir stands that varied in age from 22 to 450 years. Thinning has been shown to dramatically decrease litterfall rates for 8 to 15 years $[13,56]$, but fertilization significantly increases the rate [22], as would be predicted given the effects on height growth and associated crown recession. The mean litterfall rate found in this study was equivalent to $2433 \pm 799 \mathrm{~kg} \mathrm{ha}^{-1}$, so was similar to previously published values for Douglas-fir.

\subsubsection{Seasonal distribution}

Both foliage and fine woody litterfall peaked in the fall and early winter, concurrent with the onset of strong, windy rain storms in the Pacific Northwest [16]. Douglas-fir foliage litterfall generally peaked in October, soon after the period of maximum water stress, and minimal foliage litterfall occurred during the late winter and early spring [13, 15, 56]. Litterfall of fine woody material showed a less definite pattern but, like foliage litterfall, the majority occurred after winter storms with heavy wet snow or strong winds [56]. While the general pattern observed in the sampled Douglas-fir plantations was similar to other studies, SNC caused a slight shift in the seasonal distribution of foliage litterfall. Although most occurred in the fall, a significant amount of foliage fell in the early summer, consistent with the lifecycle of the SNC-causing fungus, Phaeocryptopus gauemannii. The lifecycle begins in the 
spring when spores are released from pseudothecia in the stomates of older infected needles and are carried by wind and rain to newly emerged needles [21]. The spores germinate on the surface of a new needle, enter through the stomates, and grow in the intercellular spaces of the leaf tissue until pseudothecia begin to appear in the fall [21]. Needles are shed when about $50 \%$ of stomata are occluded by pseudothecia [21]. The level of occlusion generally peaks in the late spring and early summer, so coincides with the secondary peak in foliage litterfall for stands with severe SNC.

Fine woody litterfall occurred primarily in the winter in this study, but shifts were observed with increasing SNC and change in aspect. SNC caused little change in the seasonal distribution of fine woody litterfall on southern aspects. On northern aspects, however, the peak in fine woody litterfall occurred later in the year for plots with severe SNC. The strength of aspect and elevation as predictors of fine woody litterfall pattern underscored the role of wind and climate in controlling litterfall.

\section{CONCLUSIONS}

Defoliation by an endemic foliar pathogen reduced LAI, influenced seasonal dynamics of LAI, and modified annual litterfall patterns. For a given stand structure, LAI was reduced $31 \%$ on sites with severe SNC, and was $33 \%$ greater in the fall than in the spring. SNC increased both foliage and fine woody litterfall, indicating a positive relationship between level of defoliation and litterfall. Severe SNC has shifted a greater proportion of the annual foliage litterfall to earlier in the spring, primarily due to the peak in fungal fruiting and occlusion of stomates just prior to budbreak. The effect of SNC on the seasonal distribution of fine woody litterfall depends on aspect and SNC severity. The documented changes in LAI and foliage and fine woody litterfall provide significant evidence that SNC may be altering several fundamental ecosystem processes such as decomposition and nutrient cycling in these Douglas-fir plantations.

Acknowledgements: We gratefully acknowledge the field assistance from Chet Behling, Jereme Frank, Jessica Samples, and Joseph Weiskittel. This study was funded by the Swiss Needle Cast Cooperative, the Oregon Department of Forestry, and the USDA-Forest Service Forest Health Monitoring program. Special thanks to Hampton Tree Farms, Longview Fiber, Oregon Department of Forestry, Plum Creek Timber Company, Green Diamond (formerly Simpson Timber), Starker Forests, and USDA Forest Service for granting access to their land. Thanks to Barbara Gartner, Greg Johnson, Everett Hansen, David Hibbs, and two anonymous reviewers for helpful comments on earlier drafts of this manuscript.

\section{REFERENCES}

[1] Albrektson A., Needle litterfall in stands of Pinus sylvestris in Sweden in relation to site quality, stand age, and latitude, Scand. J. For. Res. 3 (1988) 333-342.

[2] Arkley R.J., Glauser R., Effects of oxidant air pollutants on pine litterfall and the forest floor, in: Miller P.R. (Ed.), Symposium on effects of air pollutants on Mediterranean and temperate forest ecosystems, Pacific Southwest Forest and Range Experimental Station, USDA Forest Service, Berkeley, CA, 1980, 225 p.

[3] Balster N.J., Marshall J.D., Decreased needle longevity of fertilized Douglas-fir and grand fir in the northern Rockies, Tree Physiol. 20 (2000) 1191-1197.

[4] Bartelink H.H., Effects of stand composition and thinning in mixedspecies forests: a modeling approach applied to Douglas-fir and beech, Tree Physiol. 20 (2000) 399-406.

[5] Bille-Hansen J., Hansen K., Relation between defoliation and litterfall in some Danish Picea abies and Fagus sylvatica stands, Scand. J. For. Res. 16 (2001) 127-137.

[6] Bosveld F.C., Bouten W., Evaluation of transpiration models with observations over a Douglas-fir forest, Agric. For. Meteorol. 108 (2001) 247-264.

[7] Bouriaud O., Soudani K., Bréda N., Leaf area index from litter collection : impact of specific leaf area variability within a beech stand, Can. J. Remote Sens. 29 (2003) 371-380.

[8] Bray J.R., Gorham E., Litter production in forests of the world, Adv. Ecol. Res. 2 (1964) 101-158.

[9] Bréda N., Ground-based measurements of leaf area index: a review of methods, instruments and current controversies, J. Exp. Bot. 54 (2003) 2403-2417.

[10] Bruce D., Consistent height-growth and growth-rate estimates for remeasured plots, For. Sci. 4 (1981) 711-725.

[11] Cobb R.C., Orwig D.A., Impacts of hemlock woolly adelgid infestation on decomposition: An overview., in: Reardon R.C., Onken B.P., Lashomb L. (Eds.), Symposium on the hemlock woolly adelgid in eastern North America., New Jersey Agricultural Experiment Station, New Brunswick, NJ, 2002, pp. 317-323.

[12] Curtis R.O., A simple index of stand density for Douglas-fir, For. Sci. 28 (1982) 92-94

[13] Dimock E.J., Litterfall in a young stand of Douglas-fir, Northwest Sci. 32 (1958) 19-29.

[14] Esprey L.J., Sands P.J., Smith C.W., Understanding 3-PG using a sensitivity analysis, For. Ecol. Manage. 193 (2004) 235-250.

[15] Fogel R., Hunt G., Fungal and arboreal biomass in a western Oregon Douglas-fir ecosystem: distribution patterns and turnover, Can. J. For. Res. 9 (1979) 245-256.

[16] Gessel S.P., Turner J., Litter production in western Washington Douglas-fir stands, Forestry 49 (1976) 63-72.

[17] Gholz H.L., Environmental limits on aboveground net primary production, leaf area, and biomass in vegetation zones of the Pacific Northwest, Ecology 63 (1982) 469-481.

[18] Gower S.T., Kucharik C.J., Norman J.M., Direct and indirect estimation of lear area index, fAPAR, and net primary production of terrestrial ecosystems, Rem. Sens. Environ. 70 (1999) 29-51.

[19] Grier C.C., Foliage loss due to snow, wind, and winter-drying damage: its effects on leaf biomass of some western conifer forests, Can. J. For. Res. 18 (1988) 1097-1102.

[20] Grier C.C., Running S.W., Leaf area of mature northwestern coniferous forests: relation to site water balance, Ecology 58 (1977) 893899

[21] Hansen E.M., Stone J.K., Capitano B.R., Rosso P., Sutton W., Winton L., Kanaskie A., McWilliams M., Incidence and impact of Swiss needle cast in forest plantations of Douglas-fir in coastal Oregon, Plant Dis. 84 (2000) 773-778. 
[22] Heilman P.E., Gessel S.P., Nitrogen requirements and the biological cycling of nitrogen in Douglas-fir stands in relationship to the effects of nitrogen fertilization, Plant Soil 18 (1963) 386-402.

[23] Jonckheere I., Fleck S., Nackaerts K., Muys B., Cooppin P., Weiss M., Baret F., Review of methods for in situ leaf area index determination Part I. Theories, sensors, and hemispherical photography, Agric. For. Meteorol. 121 (2004) 19-35.

[24] Jukola-Sulonen E.L., Hokkanen T., Jalkanen R., Kleemola J., Kurka A.M., Merilä P., Niemelä P., Poikolainen J., Saronen E.M., The litter and status of Scots pine forests, in: Tikkanen E., Niemelä I. (Eds.), Kola Peninsula pollutants and forest ecosystems in Lapland: Final report of the Lapland Forest Damage Project, 1995, pp. 55-59.

[25] Kanaskie A., McWilliams M., Sprengel K., Overhulser D., Swiss needle cast aerial surveys, 1996 to 2005, in: Mainwaring D., Shaw D. (Eds.), Swiss Needle Cast Cooperative 2005 annual report, College of Forestry, Oregon State University, Corvallis, OR, 2005, pp. 9-11.

[26] Kizlinski M.L., Orwig D.A., Cobb R.C., Foster D.R., Direct and indirect ecosystem consequences of an invasive pest on forests dominated by eastern hemlock, Biogeography 29 (2002) 1489-1503.

[27] Kouki J., Hokkanen T., Long-term needle litterfall of a Scots pine (Pinus sylvestris) stand: relation to temperature factors, Oecologia 89 (1992) 176-181.

[28] Kucharik C.J., Norman J.M., Gower S.T., Measurements of branch area and adjusting leaf area index indirect measurements, Agric. For. Meteorol. 91 (1998) 69-88.

[29] Kull O., Tulva I., Modelling canopy growth and steady-state leaf area index in an aspen stand, Ann. For. Sci. 57 (2000) 611-621.

[30] Lambers H., Chapin F.S., Pons T.L., Plant physiological ecology, Springer-Verlag, New York, NY, 1998.

[31] Lehtonen A., Sievänen R., Mäkelä A., Mäkipää R., Korhonen K.T., Hokkanen T., Potential litterfall of Scots pine branches in southern Finland, Ecol. Mod. 180 (2004) 305-315.

[32] Licata J.A., Structure and physiological changes with stand age: use of process-based model to compare carbon and water fluxes in young and old-growth Douglas-fir/western hemlock forest stands, M.S. Thesis, Department of Forest Science, Oregon State University, Corvallis, OR, 2003, p. 118.

[33] Luo Y., Medlyn B., Hui D., Ellsworth D., Reynolds J., Katul G. Gross primary productivity in Duke forest: modeling synthesis of $\mathrm{CO}_{2}$ experiment and eddy-flux data, Ecol. Appl. 11 (2001) 239-252.

[34] Maguire D.A., Branch mortality and potential litterfall from Douglas-fir trees in stands of varying density, For. Ecol. Manage. 70 (1994) 41-53.

[35] Maguire D.A., Batista J.L.F., Sapwood taper models and implied sapwood volume and foliage profiles for coastal Douglas-fir, Can. J. For. Res. 26 (1996) 849-863.

[36] Maguire D.A., Bennett W.S., Patterns in the vertical distribution of foliage in young coastal Douglas-fir, Can. J. For. Res. 26 (1996) 1991-2005.

[37] Maguire D.A., Kanaskie A., The ratio of live crown length to sapwood area as a measure of crown sparseness, For. Sci. 48 (2002) 93-100.

[38] Maguire D.A., Kanaskie A., Voelker W., Johnson R., Johnson G., Growth of young Douglas-fir plantations across a gradient in Swiss needle cast severity, West. J. Appl. For. 17 (2002) 86-95.

[39] Manter D.K., Bond B.J., Kavanagh K.L., Stone J.K., Filip G.M., Modelling the impacts of the foliar pathogen, Phaeocryptopus gaeumannii, on Douglas-fir physiology: net canopy carbon assimilation, needle abscission, and growth, Ecol. Mod. 164 (2003) 211 226.

[40] Manter D.K., Winton L.M., Filip G.M., Stone J.K., Assessment of Swiss needle cast disease: temporal and spatial investigations of fungal colonization and symptom severity, Phytopathology 151 (2003) 344-351.

[41] Marshall J.D., Waring R.H., Comparison of methods of estimating leaf-area index in old-growth Douglas-fir, Ecology 67 (1986) 975979.

[42] Mitchell S., Forest health: preliminary interpretations for wind damage, Stand Density Management Diagrams, Forest Practices Branch, BC Ministry of Forestry, Victoria, BC, 2000, 40 p. http//www.for.gov.bc.ca/hfp/publications/00166/WD_29Mar00.pdf.

[43] Mohren G.M.J., Simulation of forest growth, applied to Douglas fir stands in the Netherlands, Ph.D. dissertation. Wageningen Agricultural University, Wageningen, The Netherlands, 1987, $175 \mathrm{p}$.

[44] Muukkonen P., Lehtonen A., Needle and branch biomass turnover rates of Norway spruce (Picea abies), Can. J. For. Res. 34 (2004) $2517-2527$.

[45] Piene H., Fleming R.A., Spruce budworm defoliation and growth loss in young balsam fir: spacing effects on needle fall in protected trees, For. Sci. 42 (1996) 282-289.

[46] Poikolainen J., Kubin E., On the correlation between needle litterfall and defoliation in a Scots pine stand and in a norway spruce stand, in: Aamlid D. (Ed.), Crown condition assessment in the Nordic countries: Proceedings from an intercalibration course for Northern Europe on crown condition assessment, Sundvolden, 1997, pp. 30-33.

[47] Ranger J., Gerard F., Lindemann M., Gelhaye D., Gelhaye L., Dynamics of litterfall in a chronosequence of Douglas-fir (Pseudotsuga menziesii Franco) stands in the Beaujolais mounts (France), Ann. For. Sci. 60 (2003) 475-488.

[48] Roberts J., Hopkins R., Morecroft M., Towards a predictive description of forest canopies from litter properties, Funct. Ecol. 13 (1999) 265-272.

[49] Robinson A.P., Wykoff W.R., Inputting missing height measurements using a mixed-effects modeling strategy, Can. J. For. Res. 34 (2004) 2492-2500.

[50] Rosso P.H., Hansen E.M., Predicting Swiss needle cast disease distribution and severity in young Douglas-fir plantations in coastal Oregon, Phytopathology 93 (2003) 790-798.

[51] Russell G., Marshall B., Jarvis P.G. (Eds.), Plant canopies: their growth, form and function, Cambridge University, Cambridge, UK, 1989.

[52] Sampson D.A., Albaugh T.J., Johnsen K.H., Allen H.L., Zarnoch S.J., Monthly leaf area index estimates from point-in-time measurements and needle phenology for Pinus taeda, Can. J. For. Res. 33 (2003) 2477-2490

[53] Stage A.R., An expression for the effect of aspect, slope, and habitat type on tree growth, For. Sci. 22 (1976) 457-460

[54] Thomas S.C., Winner W.E., Leaf area index of an old-growth Douglas-fir forest estimated from direct structural measurements in the canopy, Can. J. For. Res. 30 (2000) 1922-1930.

[55] Thomson A.J., Moncrieff S.M., Prediction of bud burst in Douglasfir by degree-day accumulation, Can. J. For. Res. 12 (1982) 448452. 
[56] Trofymow J.A., Barcly H.J., McCullough K.M., Annual rates and elemental concentrations of litter fall in thinned and fertilized Douglas-fir, Can. J. For. Res. 21 (1991) 1601-1615.

[57] Turnbull C.R.A., Madden J.L., Relationship of litterfall to basal area and climatic variables in cool temperate forests of southern Tasmania, Austral. J. Ecol. 8 (1983) 425-431.

[58] Turner D.P., Acker S.A., Means J.E., Garman S.L., Assessing alternative allometric algorithms for estimating leaf area of Douglas-fir trees and stands, For. Ecol. Manage. 126 (2000) 61-76.

[59] Turner J., Long J.N., Accumulation of organic matter in a series of Douglas-fir stands, Can. J. For. Res. 5 (1975) 681-690.

[60] Velazquez-Martinez A., Perry D.A., Bell T.E., Response of aboveground biomass increment, growth efficiency, and foliar nutrients to thinning, fertilization, and pruning in young Douglas-fir plantations in the central Oregon Cascades, Can. J. For. Res. 22 (1992) $1278-1289$

[61] Vogt K.A., Grier C.C., Vogt D.J., Production, turnover, and nutrient dynamics of above and belowground detritus of world forests, Adv Ecol. Res. 15 (1986) 303-377.

[62] Vose J.M., Dougherty P.M., Long J.N., Smith F.W., Gholz H.L., Curran P.J., Factors influencing the amount and distribution of leaf area of pine stands, Ecol. Bull. 43 (1994) 102-114.

[63] Vose J.M., Swank W.T., Assessing the seasonal leaf area dynamics and vertical leaf area distribution in eastern white pine (Pinus strobus L.) with a portable light meter, Tree Physiol. 7 (1990) 125134.

[64] Weiskittel A., Maguire D., Influence of Swiss needle cast on Douglas-fir stem properties, in: Mainwaring D. (Ed.), Swiss needle cast cooperative 2004 annual report, Oregon State University, College of Forestry, Corvallis, OR, 2004, pp. 91-97.

[65] Weiskittel A.R., Alterations in Douglas-fir crown structure, morphology, and dynamics imposed by the Swiss needle cast disease in the Oregon Coast Range, M.S. thesis, Oregon State University, Corvallis, OR, 2003, p. 389. http://www.holoros.com/thesis.pdf.

[66] Weiskittel A.R., Maguire D.A., Garber S.M., Kanaskie A., Influence of Swiss needle cast on foliage age class structure and vertical distribution in Douglas-fir plantations of north coastal Oregon, Can. J. For. Res. 36 (2006) 1497-1508.

[67] Weiss M., Baret F., Smith G.J., Jonckheere I., Coppin P., Review of methods for in situ leaf area index (LAI) determination Part II. Estimation of LAI, errors and sampling, Agric. For. Meteorol. 121 (2004) $37-53$

[68] White M.A., Thorton P.E., Running S.W., Nemani R. Parameterization and sensitivity analysis of the BIOME-BGC terrestrial ecosystem model: net primary production controls, Earth Interactions 4 (2000) $1-46$

[69] Whitehead D., Kelliher F.M., Frampton C.M., Godfrey M.J.S., Seasonal development of leaf area in a young, widely spaced Pinus radiata D. Don stand, Tree Physiol. 14 (1994) 1019-1038. 